\title{
KARŞILAŞTIRMALI HUKUKTA SÖZLEŞME ÖZGÜRLÜĞÜNÜN SINIRLANDIRILMASI
}

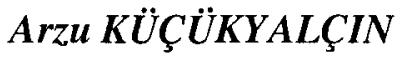

\section{GİRIŞ}

Sözleşme özgürlüğü ilkesi, Avrupa Sözleşmeler Hukukunda olduğu gibi, tüm çağdaş hukuk düzenlerinde 19. yüzyıldan bu yana benimsenerek uygulanmış olan temel bir ilkedir. Toplumsal ilişkilerin düzenlenmesinde hukukî ve sosyo-ekonomik bir araç olan sözleşmenin, tarafların serbest iradelerinin karşılıklı olarak mutabakata varması sonucu akdedilmesi, şüphesiz ki gerekli ve önemli; ayrıca hukukî olarak da meşrudur. Ancak, tarih boyunca toplumsal ilişkilerin geçirdiği hızlı sosyal ve ekonomik değişimler, bu ilkenin tanıdığı olanakların ekonomik ve sosyal açıdan güçlü kişilerce kötüye kullanılmasına neden olmuştur.

Toplumsal ilişkilerin her alanda düzenlenmesine büyük ölçüde yardımcı olan en gerekli ve temel araç olan sözleşmenin, hukukî işlevini tam anlamıyla yerine getirebilmesi için ise, sözleşme özgürlüğü ilkesine duyulan ihtiyaç büyüktür. Bu nedenle, sözleşme hukukunun olmazsa olmaz yapı taşı olan bu ilkenin, hakkaniyete uygun ve meşru bir zeminde kullanılması gerekmektedir. Bundan dolayı, çağdaş hukuk düzenleri ve Avrupa Sözleşmeler Hukuku, sözleşme özgürlüğü ilkesinin, sözleşme hukukuna en makul seviyede teşmilinin çaresini, bu ilkeyi belli ölçülerde sınırlandırmakta bulmuştur.

Çalı̧̧mamızda, konunun Roma Hukukundaki temellerinden günümüze kadar geçirmiş olduğu değişiklikler ve yenilikler üç bölüm halinde incelenmiştir. Ius Commune bakış açısıyla yapılan incelemelerin ardından; özellikle Türk hukukunda olmak üzere, Kıta Avrupası hukuk sistemini benimsemiş belli bazı çağdaş hukuk düzenlerinde ve Common Law sisteminde sözleşme özgürlügü ilkesinin ne şekilde sınırlandırıldığı, bir ölçüde karşılaştırma yapılabilmesi amacıyla incelenmiştir. 


\section{BİRINCI BÖLÜM \\ ROMA HUKUKU'NDA SÖZLEŞME ÖZGÜRLÜĞÜ}

\section{I- Roma Hukuku'nda Sözleşme}

\section{A) Roma Hukuku'nda "Hukukî İşlem” Kavramı}

Roma Hukuku'nda hukukî işlem konusunda genel bir öğreti yer almamaktadır. Roma Hukuku kaynaklarında sıklıkla olmasa da karşılaşılan "negotium" kavramı ise, sanıldığının aksine teknik olarak "ekonomik anlamda faaliyet" kavramına karşllık gelen bir terimi ifade etmektedir. Ancak Roma Hukukçuları, teorik olmaktan ziyade uygulayıcı oldukları için, tek tek hukukî işlem çeşitlerinin şartlarını ve özelliklerini inceleyip saptamak suretiyle bütün bu hukukî işlemlerde ortak olan noktaları tespit ederek ayrıntılı olarak incelemişler ve böylelikle hukukî işlem kavramını "uygulama" yoluyla yerleştirmişlerdir".

Roma Hukuku'nu sistemleştiren Alman Pandekt hukukçuları ise, Roma hukukçularının uygulamada yerleştirdikleri hukukî işlem türlerini inceleyerek genel kavram ve kuralları saptamışlar; bu kuralları belirli bir sistem içinde toplamışlar ve "negotium iuris" terimini oluşturarak hukukî işlem kavramının sistematiğini kurmuşlardır ${ }^{2}$. Bu sistematik, modern özel hukuk sistemlerine şu şekilde işlenerek aktarılmıştır: "Bir veya birden çok kişinin hukuk düzeninin öngördüğü sınırlar içinde gerektiğinde diğer unsurlarla birlikte hukukî sonuçlar doğurmaya yönelmiş irade açıklaması veya açıklamalarından oluşan hukukî bir olgudur." "3. Hukukî işlem, hukukî sonuca yönelik olarak yapılmış bir irade açıklamasıdır. Bir sosyal ilişkinin hukukî işlemden doğan borç ilişkisi sayılabilmesi için ise, bir iradenin varlı ̆̆l, bu iradenin açıklanması ve hukukî sonuç gerekir ${ }^{4}$.

\section{B) Roma Hukuku'nda "Sözleşme" Kavramı}

Roma Hukukunda sinırlı sayı ilkesi (numerus clausus) benimsendiği için, Roma Borçlar Hukukundaki günümüz modern hukuk sistemlerindeki "sözleşme" kavramını tam olarak karşılamayan "contractus" kavramı,

\footnotetext{
${ }^{1}$ Koschaker, P./ Ayiter, K.: Modern Hususî Hukuka Giriş Olarak Roma Hususî Hukukunun Ana Hatları, Ankara 1975, s.54 vd.; Karadeniz-Çelebican, Ö.: Roma Hukuku, AÜHF Yay. No.518, Ankara 1997, s.191.

${ }^{2}$ Zimmerman. R.: The Law of Obligations, Roman Foundations of the Civilian Tradition, Johannesburg 1992, s. 45.

${ }^{3}$ Merz, H.:Vertrag und Vertragschluss, Freiburg 1988,s.3; Köhler, H.: BGB, Allgemeiner Teil, 18. A., München 1983, s.108.

` Kılıçoğlu, M. A.: Borçlar Hukuku Genel Hükümler, Cilt I, Ankara 2001, s.25 vd.; Eren, F. Borçlar Hukuku Genel Hükümler, C.I, İstanbul 1998, s.116 vd..
} 
sadece ius civile tarafından geçerli sayılarak belirli hüküm ve sonuçlara bağlanan sözleşmeleri ifade etmektedir. Ius civile kapsamına girmeyen geri kalan tüm sözleşmeler ise, İmparator Hukuku tarafından tanınan "pactum"ları oluşturmaktadır. Contractus ve pactumları ayırdedici husus, contractusun, ius civile tarafından tanınan bir actio ile yaptırıma bağlanmış bir akit olmasıdır 5 .

\section{II- Roma Hukuku Sözleşmeler Sistemi ve Sözleşme Özgürlüğünün Denetimi}

\section{A) Sistemin Temel Yapısı}

Günümüzdeki modern hukuk sistemleri ile Roma Hukuku'nun arasındaki temel sistem farkı, Roma Hukuku'nda sözleşme özgürlüğünün olmamasıdır. Bu durumun temel nedeni, ius civile'nin borcun doğumu için sadece tarafların rızalarını (consensus) yeterli görmemesidir. Ancak, zamanla gelişen ticarî hayatın gereklerini karşılanması zorunluluğu ve pretorların faaliyetleri sonucu, istisnaî hallerde, sadece rıza borcun doğumu için yeterli kabul edilmeye başlanmıştır ${ }^{6}$.

Roma Hukuku'nda çoğu sözleşmenin borç doğuracağı ve actio- dava ile takip edilebileceği pretorların tanıdığı koruma ve Imparatorların constitutio'ları ile kabul edilmiş olmasına rağmen, modern hukuk sistemlerinde benimsenen sözleşme özgürlüğü ilkesine ulaşılamamıştır. Ulaştığımız bu sonuç, Roma Hukuku sözleşmeler sisteminin münferit ve muayyen sözleşmelerden müteşekkil bir sistem olmasının aynı zamanda nedenini teşkil etmektedir?

Sözleşmede öngörülen edim veya yükümlülüklerin dengelenmesinin gerekli olup olmadığı sorusuna, Klasik Roma Hukuku olumsuz cevap vermekte idi ve bundan dolayı, bir satım sözleşmesinde satılan şeyin değeri ile sözleşmede öngörülen bedel arasında bir dengesizlik, oransızlık olması halinde dahi sözleşme geçerli kabul edilmekte idi. İlk olarak, Corpus Iuris Döneminde, bir arsanın satımını konu alan sözleşmede, arsanın değerinin yarısından az miktarda bedel verilmesi halinde, emirnamelerle ${ }^{8}$, satıcıya sözleşmeyi feshetme yetkisi verilmiştir. Bu emirnamede, açıkça sosyopolitik bir amaç güdülerek sözleşme özgürlüğü sınırlandırılmıştır. Güdülen sosyo-politik amaç, o dönemin imparatorlarının vergi politikası nedeniyle

\footnotetext{
${ }^{5}$ Koschaker/ Ayiter, s.205; Meyer, R./Spasche, A.: Roman Law, The Recovery of Benefits Conferred under Illegal or Immoral Transactions, Uni. of Aberdeen 2002, s.5, www .abdn.uk, 10.12.2003.

${ }^{6}$ Karadeniz-Çelebican, s.219.

${ }^{7}$ Rado, T.: Roma Hukuku Dersleri, "Borçlar Hukuku”, İstanbul 1997, s.60-61.

${ }^{8}$ Söz konusu emirnamenin M.S. 3. veya 6. yy.'da yürürlükte olduğu tahmin edilmektedir. Tarihi konusunda kesinlik yoktur.
} 
yoksullaşan çiftçilerin arazilerini şehirli sermaye sahiplerine düşük bedellerle satmak zorunda kalmalarını önlemekti. Roma Hukukunda, çeşitli emirnamelerle başlatılan bu uygulama, daha sonra laesio enormis (adil sözleşme koşulları) ilkesi adını almıştır ${ }^{9}$. Laesio enormis ilkesinin temelinde, kökleşmiş bir "adil olma" anlayışı yatmaktadır. Bu anlayışa göre, taraflardan birinin ediminin diğerinin yarısı oranında veya daha az olması halinde, karşı tarafa, sözleşmeyi hükümsüz kılma imkanı verilmektedir ${ }^{10}$.

\section{B) Sözleşme Tipleri}

Gaius ve Iustinianus'un Institutiones'inde, sözleşmeler dört gruba ayrılarak incelenmiştir. Bunlar; aynî, sözlü, yazılı ve rızaî sözleşmelerdir ${ }^{11}$.

Aynî bir sözleşmenin kurulması için tarafların birbirine uygun rızası ve borçlunun alacaklıdan bir şey "res" alması gerekmektedir. Aynî sözleşmeye verilebilecek en klasik örnek, ödünç veya karz sözleşmesi olarak nitelendirilen "mutuum"dur".

Sözlü sözleşmelerin kurulabilmesi için ise, tarafların rızalarının sözlü ve belirli şekilde yapılması gerekir. Klasik dönemde en yaygın uygulama alanı bulan sözlü sözleşme, "stipulatio"dur. Stipulatio sözleşmesi, bir tarafın sorusu diğer tarafın cevabı ile meydana gelmekteydi ${ }^{13}$.

Yazılı sözleşmeler de, yazılı olarak aktedildikleri takdirde geçerli kabul edilirler. Roma Hukuku'nda yazılı sözleşmeler, günümüz yazılı sözleşmelerinden tamamıyla farklı özelliğe sahiptirler. Roma'da "nomen transeriptitium" denilen yazılı sözleşmeler, aile reisinin günlük hesap defterine bir takım kayıtların geçirilmesi suretiyle oluşturulmakta idi ${ }^{14}$.

Rızaî sözleşmeler ise, sadece tarafların rızalarının varlığı ile kurulabilir. Bir şeyin verilmesi ya da belli bir şekle uyulması zorunluluğu yoktur. Roma Hukuku'nda sadece dört sözleşme tipinde; alım satımda (emptio venditio), kira, hizmet, istisnada (locatio conductio), şirket (societas) ve vekalet (mandatum) akitlerinde rızaların beyan edilmesi yeterli görülmüşsürr ${ }^{15}$.

${ }^{9}$ Kötz, H.: Europäisches Vertragsrecht, Band I, Abschluss, Gültigkeit und Inhalt des Vertrages, die Beteiligung Dritter am Vertrag, Tübingen 1996, s.198-199.

${ }^{10} \mathrm{Kötz}$, age, s.206.

${ }^{11}$ Iustinianus: Institutiones (Çev. Ziya Umur), İstanbul 1968, s.239; Sohm, R : The Institutes (Çev. James Crawford Ledlie), W.M.W Gaunt\& Sons. Inc. 1994, s.372.

${ }^{12}$ Rado, age, s.62.

${ }^{13}$ Rado, age, s.62-63.

${ }^{14}$ Meyer-Spasche, agm, s.5; Rado, age, s.63.

${ }^{15}$ Meyer-Spasche, agm, s.5; Rado, age,s.63. 


\section{İKINCİ BÖLÜM SÖZLEŞME ÖZGÜRLÜĞÜNÜN GELIŞSIMI Sözleşme Özgürlüğünün Ortaya Çıkışı}

Ortaçağda feodal toplum düzeninin hüküm sürmesi nedeniyle, bu sistemin temelini oluşturan toprak mülkiyeti, kişiler açısından sabit konumlar (statüler) belirlemekteydi ${ }^{16}$. Dolayısıyla kişilerin statüleri gereği, diledikleri alanda serbestçe sözleşme kurmaları ve bu sözleşmelerin hukukî sonuç doğurması beklenemezdi.

17. ve 18. yüzyıllarda ise, bireyin özgürlüğünü ilan eden düşünce akımları ${ }^{17}$ ortaya çıkmış ve bu akımlar siyasi ve toplumsal etkisini 1789 Fransız Devrimi ile göstermiştir. 18, yy.'da başlayan ve 19.yy.'da tam olarak yaşanan "Endüstri Devrimi" ise, endüstri toplumunu oluşturarak endüstriyel imalât yapan "serbest işletmeci modeli"ni hakim kılmıştır"1.

19. yy.'da ise, klasik liberal iktisat teorisinin temelini atan Adam Smith'in "Bırakınız yapsınlar, bırakınız geçsinler" şeklindeki tespitinde, piyasadaki fiyat oluşumuna hukukî yollarla müdahale ederek sözleşme eşitliğini sağlamaya çalışmanın pazar dengesini bozacağı, ifade edilmiştir ${ }^{19}$. İrade muhtariyeti ise, başlangıçta hukukî olmayan, kökeni itibariyle devletin sosyal hayattaki koruyucu (paternalist) politikalarının reddedilerek tarafların her alanda özgürlüğünü tesis etmeyi ilke edinmiş ekonomik ve politik bir hareket olarak kabul edilmiştir ${ }^{20}$. Bu durumda, devletin devreye gireceği tek durum, pazarın piyasa fiyatı etrafında oluşabilmesi için gerekli olan sosyal ve siyasal çerçeve koşullarını sağlamaktır. Kapitalist ekonomi düzeninde, kişilerin ihtiyacı olan piyasa aracılığını sağlayacak ilişkinin sahip olması gereken hukukî kalıbın "sözleşme" olduğu kabul edilmektedir ${ }^{21}$.

Sözleşme özgürlüğü ilkesinin, taraflara iliş̧ilerini yasal çerçeve içinde serbestçe şekillendirme imkanı verdiği kabul edilmekte olup ${ }^{22} ; 19$. yy. "sözleşme yılları" olarak kabul edilmiştir ${ }^{23}$. 19. yy.'da çă̆daş hukuk düzenlerinin temelleri şekillenmeye başlarken, hukuk düzenleri âkit taraflara akdin şartlarını genel olarak serbest iradeleriyle kararlaştırabilecekleri bir

\footnotetext{
${ }^{16}$ Sirmen, L.: Modern Hukukta Sözleşme Kavramı ve Türk Hukuku, Cahit Oğuzoğlu'na Armağan, Ankara 1972, s.441-442.

${ }^{17}$ Hümanizm, aydınlanma, doğal hukuk felsefesi, fizyokratların ekonomik öğretileri.

${ }^{18}$ Wieacker, F.: Pandektwissenschaft und industrielle Revolution", Juristen Jahrbuch, 9 Band 1968-1969, s.1-2.

${ }^{19}$ Smith, A.: An Inqurry into the Nature and the Causes of the Wealth of Nations, London 1776.

${ }^{20}$ Isaacs, N.: The Standardizing of Contracts, Yale Law Journal, C.27, 1917-1918, s.34.

${ }^{21}$ Zöllner, W :: Die Privatrechtsgesellschaft im Gesetzes und Richterstaat, Köln 1996, s.24.

${ }^{22}$ Huber, H.: Die Verfassungsrechtliche Bedeutung der Vertragsfreiheit, Berlin 1966, s.14.

${ }^{23}$ Hurst, J. W.: Law and the Conditions of Freedom in the Nineteenth Century United States, 1956, s.18.
} 
alan bırakarak sözleşme özgürlüğu (freedom of contract) ilkesini kabul etmiştir. 19. yy.'dan itibaren sözleşme hukukuna hakim olan bu ilke, sözleşmeler bireysel alanda kaldığı, yani sözleşme şartları taraflarca münferiden müzakere edilebildiği sürece (individualism) iyi işlemiş ve bu süreç bir yüzyıl kadar sürmüştür ${ }^{24}$.

\section{II- Sözleşme Özgürlüğünün Kodifikasyon Hareketleri Üzerindeki Etkileri}

19. yy.'dan 20. yy.'a geçerken arka arkaya bütün Avrupa ülkelerinde kodifikasyon hareketleri gündeme gelmiştir. Devletler kendi sınırları içerisinde yeknesak uygulamaya sahip olabilecek ve hukuk birliğini sağlayacak hukuk düzenleri yaratma yolunda çalışmalara başlamıştır. Hukuk birliğini sağlama amacının iki önemli ve temel esasa dayandığı ileri sürülmektediri ${ }^{25}$ :

- Devlet ve toplum arasındaki sınırın çizilmesiyle kişilerin özgürce hukukî ilişkilerini oluşturması,

- Ekonomik alanda yaşanan gelişmeler ile serbest piyasa ekonomisinin bütün Avrupa'da uygulanmaya başlaması ve eski feodal toplum düzeninin gereklerine cevap veren hukuk düzenlerinin yenilenmesi ihtiyacidir.

19. yy.'ın başlarında üç önemli kodifikasyon hareketi yaşanmıştır. Bunlar; 18. yy.'in sonunda kabul edilen Prusya Medenî Kanunu, 1804 tarihinde kabul edilen doğal hukuk ve özgürlük arayışlarının en güzel temsilcisi olan Fransız Medenî Kanunu ve 1811 tarihli Avusturya Medenî Kanunu'dur. Fransız Medenî Kanununda sözleşme hukukunu, "sözleşme özgürlügüu" ve "sözleşmeye sadakat" düşünceleri belirlemiştir. 19. yy. hukukçuları, "Sözleşme ile karalaştırılan her zaman adildir." ilkesini benimsedikleri için, sözleşme özgürlüğü ilkesi, Fransız Medeni Kanununda kendisini göstermiştir. Bu sebeple de, Kanun, sözleşme özgürlüğünün sınırlandırılması alanında, birkaç özel norm dışında, kamu düzeni ve ahlâka aykırılık vasıtasıyla sözleşmelerin denetimini öngörmüştür. Sözleşmeye sadakat ( pacta sunt servanda) ilkesi ise, sözleşme özgürlüğü ilkesinin tamamlayıcısı olarak kabul edilmiş ve Fransız Medenî Kanunu md.1134'te, hukuka uygun olarak meydana gelmiş olan sözleşmelerin "kanun" hükmünde olduğu kabul edilmiştir ${ }^{26}$.

\footnotetext{
${ }^{24}$ Güngör, G.: Milletlerarası Özel Hukukta Tüketicinin Korunması, Ankara, 2000, s.35-36.

${ }^{25}$ Atamer, Y.: Sözleşme Özgürlüğünün Sınırlandırılması Sorunu Çerçevesinde Genel İşlem Şartlarının Denetlenmesi, İstanbul 2001, s.16-17, (Genel İşlem Şartlarının Denetlenmesi).

${ }^{26}$ Atamer, age, s. 18.
} 
Alman Medenî Kanunu da aynı ilkelerin benimsenmesiyle oluşturulmuş ve $\mathrm{BGB}^{27}$ 305. maddesinde sözleşme özgürlüğü ilkesi benimsenmiştir. Alman hukukunda ve doktrininde, Kant'in teorileri doğrultusunda, kișilerin devlet müdahalesinden uzak bir hukukî alanda irade egemenliğine sahip olmaları ve bu egemenliğin husule getirdiği irade beyanı ve bu irade beyanının yansıması, "sözleşme" olarak ele alınmıştır 28 .

\section{ÜÇÜNCÜ BÖLÜM \\ GÜNÜMÜZDE SÖZLEŞME ÖZGÜRLÜĞÜNÜN DENETIMI \\ I- Kıta Avrupası Hukuk Sisteminde Sözleşme Özgürlüğünün Denetimi \\ B- Genel Olarak \\ Ortaçağın başlarından 18. yy.'ın sonlarına kadar orta ve batı Avrupa'da hukukun temelini oluşturan Roma-Kilise hukuku, günümüz Kıta Avrupası Hukuk sisteminin ortak kökeni olan Ius Commune'yi teșkil etmektedir ${ }^{29}$. Hatta, 11. yy.'dan 18. yy. sonlarına kadar bir "hukuk birliği" döneminin yaşandığı ileri sürülmektedir ${ }^{30}$. Roma hukukundan çıkarılan Ius Commune, Ius Commune anlayışına sahip Avrupa hukukçuları tarafından:}

- Ulusal normları ve teamül kurallarını tamamlayıcı rol oynayan ikincil nitelikte bir hukuk kaynağı veya

- Hukuk kavramlarının belirlenmesinde ve yorumlanmasında başvurulan genel bir hukuk kaynağ 1

olarak anlaşılmıştır ${ }^{31}$. Bu anlayış, kendisini 19. yy.'da Almanya'da Pandekt hukukunda geçerliliğini sürdürmüss ve Avrupa'da yapılan kodifikasyon hareketlerinde Ius Commune'nin ilkeleri kural haline getirilerek Avrupa'nın ortak medenî hukuk kökeni muhafaza edilmiştir ${ }^{32}$.

Ius Commune ile ilgili açıklamalarımızla varmaya çalıştığımız nokta, incelemekte olduğumuz sözleşme özgürlüğünün denetimi konusunun, diğer pek çok hukukî konuda olduğu gibi, Kıta Avrupası hukuk sistemini benimsemiş ülkelerde, belli bazı ortak unsurlara, ilkelere, amaçlara ve benzerliklere sahip olmasının hukukî ve tarihî açıdan temel ve gerekçesini ortaya koymaktır.

\footnotetext{
${ }^{27}$ Bürgerliches Gesetzbuch: "medenî kanun".

${ }^{28}$ Hönn, G.: Kompensation gestörter Vertragspäritat, München 1982, s.9-12.

${ }^{29}$ Oğuz, A.: Karşılaştırmalı Hukuk, Ankara 2003, s.56.

${ }^{30}$ Oğuz, A.: Sözleşmeler Hukuku Alanında Hukukun Birleştirilmesi, AÜHFD 2000, S.1 , s.36.

${ }^{3 !}$ Basedow, J.: Avrupa Özel Hukukunun Doğuşu, (Çev.: Arzu Oğuz,) AÜHFD 2003, C.52, S.3, s.2.

${ }^{32}$ Oğuz, Karşılaştırmalı Hukuk, s.57-58.
} 
Sözleşme hukukunun tarihi, özgürlük arayışı ve bulunan özgürlüğün sınırlanması çabalarından müteşekkildir. Beşerî anlamda özgürlük, etik olarak, tıpkı bir hukuki kavram gibi doğal ve tarihsel olarak insanın kendini sınırlamasına karşılık gelen bir kavramdır. Sözleşme özgürlüğü müspet bir hukukî müessese olarak kabul edilmiş ve medenî hukukun önemli bir yapısal unsuru haline gelmiştir ${ }^{33}$. Sözleşme adaletinin sağlanması amacıyla, sözleşme özgürlüğüne müdahale kaçınılmazdır. Denkleştirici adalet (iustitia commutativa) düşüncesi üzerine kurulu olan sözleşme özgürlüğ $\mathfrak{u}^{34}$, temel bir ilke olan sosyal devlet ilkesi ile uzlaştırılarak sosyal adalet düşüncesi ile, kişinin kendisine tanınan özgürlükleri kullanamadığı alanlarda müdahale edilmesini temin eder ${ }^{35}$. Sözleşme özgürlüğü, bireyin özgür iradesine bağlı olarak gelişmiştir. Grotius ve Pufendorf da, sözleşme özgürlüğünü bu düşünce üzerine temellendirmiş ve hatta bir ilke haline getirmeye çalışmışlardır. Kant, bu saptamanın yerine bireyin ahlakî otonomisi üzerine doğal hukukun sosyo-etik kuralı olarak sözleşme özgürlüğünü tesis etmiştir. Savigny ise, 19. yy. sonunda sözleşme özgürlüğü ilkesine son şeklini vermiştir. Yüzyıllar boyunca süregelen " status'lardan sözleşmelere" şeklinde bir gelişim vardır ve bu gelişim sürecinde hukuki koruma koşulu içeren sözleşme tipleri çoğalmıştır ${ }^{36}$.

Günümüzde Kıta Avrupası Hukuk sistemini benimsemiş olan hukuk düzenlerinde, sözleşme özgürlüğünün denetimi, genel olarak kategorize edilmiş üç gruba istinaden incelenmektedir ${ }^{37}$ :

1. Düzenli sözleşmeler

2. Haksız sözleşmeler

3. Genel işlem şartlarının denetlenmesi

\section{1-Düzenli Sözleşmeler}

Sözleşme özgürlügüüün smırlandırılması, düzenli sözleşmelerde:

- kiracının korunması,

- hizmet sözleşmelerinde işçinin korunması,

- tüketicinin korunmas1

mülahazalarıyla, belirli bir sözleşmenin içeriğinin emredici kurallara göre denetlenmesiyle söz konusu olmaktadır. Burada temel ve meşru gerekçe zayıf âkit tarafın korunmasıdır. Zayıf âkit tarafı korumak ve

\footnotetext{
${ }^{33}$ Raiser L.:Vertragsfreiheit Heute, Juristenzeitung, No: 1, Tübingen, 5.Ocak 1958, s.1.

${ }^{34}$ Kötz, age,s. 171.

${ }^{35}$ Atamer, age, s.26-27.

${ }^{36}$ Raiser, agm, s. 2.

${ }^{37}$ Kötz, age, s. 193.
} 
sözleşme özgürlügüu bağlamında akdî eşitliği tesis etmek amacıyla özellikle, kira, hizmet ve tüketici sözleşmelerinde kiracı, tüketici ve işçinin korunmasını amaçlayan emredici kuralların sevkedilmesiyle sözleşme özgürlüğünün sınırlanması gündeme gelmiştir. ${ }^{38}$.

\section{2-Haksız Sözleşme Şartları Taşıyan Sözleşmeler}

Adil olmayan sözleşmelerde sözleşme özgürlüğünün sınırlandırılması, iki temel üzerine kuruludur:

- tarafların edim ve yükümlülükleri arasındaki dengesizlik ve

- bir tarafin zaruri durumundan faydalanılmasi

Edimler arası dengesizlik nedeniyle sözleşmenin geçersizliği, ilk olarak Orta çağda, geniş bir çerçevede geliştirilmeye başlanmıştır. Thomas von Aquin ve diğer din adamları, sözleşmenin içerdiği edimler arasında eşit bir denge olması gerektiğini ve bir kişinin karşı âkide adil bir bedel ( Iustum Pretium )ödemeyi vaadetmesi ve ödemesi gerektiğini, aksine bir durumun "günah" sayılacağını ve laesio enormis ilkesi nedeniyle sözleşmenin feshedilebileceğini ifade etmiştir ${ }^{39}$. 19. yy. başında yürürlïğe giren medenî kanunlar, laesio enormis ilkesine geniş ölçüde yer vermişlerdir. Avusturya Medenî Kanunu, bu ilkeye en geniş ölçüde yer vermiş olan kanundur. Anılan Kanunun 934. maddesi, sözleşmenin her iki tarafına, bir edimin karşı edimin değerinin yarısından az olması halinde, sözleşmeyi feshetme imkanını tanımıştır.

Bir âkid tarafın zarurî durumundan faydalanılması hali ile ilgili düzenlemeler, yeni medenî kanunlarda pek fazla kabul görmemiştir. Ancak, yeterli derecede zekî ve ticarî işlem kabiliyetine sahip bir kişinin sözleşme özgürlüğ̈̈u, rekabet özgürlüğü ve sinaî özgürlüklerden faydalanarak ve kendini zarardan kurtararak girişimde bulunması için, hakime sözleşmenin içeriğinin denetlenmesi yetkisini veren bir kuralın getirilmesi gerekliliği fark edilmiştir. Avrupa medenî kanunlarının çoğu şöyle bir çözüm tarzını benimsemişlerdir: Bir sözleşmenin akdedilmesinde veya sözleşmenin bir şartının yerine getirilmesinde, âkid taraflardan birine haksız bir şekilde aşkın bir avantaj sağlayan, bu sözleşme veya şart, geçersiz kabul edilmelidir. Zîra burada, sözleşmenin amacı veya yapısından, sözleşmeden haksız şekilde avantaj sağlayan tarafın, karşı tarafın ekonomik durumunun zaruretinden, tecrübesizliğinden, pazarlık gücünün zayıflığından ve bu nedenlerle bağımlılığından yararlanarak haksız avantaj sağlaması söz konusudur. Bu çözüm tarzının birçok medenî kanunda yer alıyor olmasına karşın, uluslararası ticarî sözleşmelerde öncelikle UNIDROIT ilkelerinin geçerli

\footnotetext{
${ }^{38}$ Kötz, age, s. 192.

${ }^{39}$ Kötz, age, s. 199. Konunun Roma hukukunda inceleniş tarzı için bkz. yuk. s.4.
} 
kabul edilmesi, ilgi ve şaşkınlıkla karşılanması gereken bir durum olarak kabul edilmektedir ${ }^{40}$.

Laesio Enormis ilkesi tek fonksiyonlu bir mekanizma olması gerekçesiyle eleştirilere maruz kalmıştır. Zira, bir sözleşmede edimlerin karşılıklı oransızlığı, sözleşmeyi geçersiz kılacaksa, piyasa işleyişinin de bozulması gündeme gelecektir. Edimlerarası dengesizliğin, sözleşmeyi geçersiz k1lmak için yeterli kabul edilmemesi durumunda, hangi faktörlerin devreye girmesi gerektiği tartışılmıştır. Bu noktada yasakoyuculardan fazla bir yardımın beklenmemesi gerektiği, yasakoyucuların sadece genel ilkelerle, ahlâka aykırılık, şartların suiistimali, aşırılık halinde sözleşmenin geçersizliği hallerinde olduğu gibi, çözüm üretebileceği ileri sürülmüştür. Bu noktada, pazarlık gücünün eşitsizliğine istinaden, edimlerin dengesizliği ile sözleşmenin geçersizliği, hafif derecede yardım sağlar. Bu nedenle, her somut olayda, sözleșmenin geçersiz kabul edilebilmesi için yeterli derecede eşitsizliğin olup olmadığı araştırılmalıdır ${ }^{41}$.

\section{3- Genel İşlem Şartları ve Denetlenmesi}

20. yy.'da sözleşmelerinin yapılmasının esaslı surette değişmesi, yüksek üretimin ekonominin ayrılmaz bir parçası haline gelmesi, mal ve hizmet üretiminin yüksek boyutlara ulaşması, mal ve hizmet sunan kişilerin işletme kârlılığını sağlayabilme endişesi gibi sebeplerle, çağdaş hukuk düzenleri ticaret hayatının gereklerini de yerine getirmek amacıyla, sözleşmelerin giderek artan bir biçimde önceden formüle edilmiş standart sözleşmelere dönüşmesine yol açmıştır. Sözleşme özgürlüğü ilkesinin hukuk düzenlerinde yerini almasıyla birlikte, standart biçimde yapılan akitler kendisine dayanak bularak yaygınlaşmıştır. Nitekim Friedrich Kessler, özellikle sınaî ve ticarî güçlerin eline geçen standart sözleşmelerin o kesime yeni bir feodal düzen kurma imkanı verdiğini iddia etmiştir ${ }^{42}$.

Standart sözleşmeler, yazılı ve önceden hazırlanmış sözleşmeler olup genel olarak,

- model sözleşmeler (model contracts) ${ }^{43}$ veya

- katılma akitleri (iltihakî sözleşmeler / tip sözleşmeler / contracts of adhesion/ genel işlem şartlarıyla yapılan sözleşmeler

\footnotetext{
4t) Kötz, age, s. 201.

${ }^{41} \mathrm{Kötz}$, age, s.206.

${ }^{42} \mathrm{Kötz}$, age, s.211.

${ }^{43}$ Model sözleşmeler, tarafların pazarlık gücünün eşit olduğu, sözleşme şartlarının tarafların ekonomik menfaatleri arasında bir denge sağlanması amacıyla müzakere edilerek sözleşmeye konulduğu milletlerarası ticareti konu edinen hukukî işlemlerde sıkça kullanılan sözleşmelerdir.
} 
şeklinde meydana getirilmektedir ${ }^{44}$.

Çalışmamızın konusunu doğrudan ilgilendiren genel işlem şartlarıyla yapılan sözleşmeler ise, yapılışlarına ilişkin yöntem itibariyle 20. yy.'ın başında Raymond Saleilles tarafından Fransız hukuku için ortaya atılan katılma sözleşmesi ${ }^{45}$ olarak adlandırılan ve bir tarafın, sözleşmenin şartlarını tek taraflı olarak, karşı âkidin ihtiyaç ve özelliklerini dikkate almadan tespit ettiği, sözleşmenin niteliği ne olursa olsun aynı tür sözleşmeleri mutaden hep belirli bir şekilde yaptığı ve bu tipten hemen hiç ayrılmadığı standart sözleşmelerdir ${ }^{46}$.

Genel işlem şartlarının unsurlarını şu şekilde sıralamak mümkündür ${ }^{47}$ :

- Bir sözleşmenin şartlarını oluşturmaları,

- Sözleşmenin kurulmasından önce düzenlenmeleri,

- Birden fazla sözleşme ilişkisinde kullanılmak üzere düzenlenmeleri,

- Genel işlem şartlarını kullanan tarafından sözleşmeye dahil edilmek niyetiyle karşı âkide sunulmalarıdır.

Genel işlem şartlarına ilişkin çok çeşitli tanımlar yapılmıştır. Bunlardan birkaçına değinmek, konunun daha net bir şekilde kavranmasını sağlayacaktır. Alman hukuku doktrininde ağırlığı olan birkaç yazara değinilecek olursak; Raiser'e göre, genel işlem şartı benzer nitelikte hukukî işlemler için formüle edilmiş soyut ifadelerle kaleme alınmış şartlar; Lukes'e göre, sözleşme içeriğinin önceden formüle edilmesine yarayan kayıtlar; Schumann'a göre, normlaştırılmış sözleşme hükümleri; Salzer'e göre ise, sözleşmenin talî noktalarını düzenlemek amacıyla sözleşme metninin dışında önceden hazırlanıp atıfta sözleşme içine alınan kayıtlardır. İsviçre hukukunda yapılan tanımlamalara değinmek gerekirse; Schönenberger, Kramer, Bühler ve Bauer gibi yazarlara göre, standart sözleşme içinde yer alan önceden hazırlanmış şartlar, Merz'e göre, çok sayıda yapılacak sözleşmelerin standart hale getirilmesi amacıyla metin içine alınan şartlar; Neagli'ye göre ise, bir tek sözleşme ilişkisini düzenlemek için düşünülmeyen aksine çok sayıda sözleşme ilişkisini standart hale getirmek üzere hazırlanan şartlar, genel işlem şartlarıdır ${ }^{48}$.

Alman hukukunda, Genel İşlem Şartları Hukukunun Düzenlenmesine İlişkin Kanun'un ${ }^{49}$ md.1/1'de yer alan tanıma göre ise, "Genel işlem şartları,

\footnotetext{
${ }^{44}$ Güngör, age, s.37.

${ }^{45}$ Sadece kamusal bir makamla aktedilen sözleşmeler için kullanılmaktadır.

${ }^{46}$ Atamer, age, s.7; Güngör, age, s.38.

${ }^{47}$ Atamer, age, s.62-69.

48 Yavuz, N.: Genel İşlem Şartlarının Tanımı, Yorumu ve Denetlenmesi, Yargıtay Dergisi, 1999, C.25, S.4, s.571-572.

49 BGBl. I S.3317, 9 Aralık 1976'da kabul edilmiş, 1 Nisan 1977'de yürürlüğge girmiştir.
} 
çok sayıda sözleşme için önceden düzenlenmiş olan ve sözleşme taraflarından, şartları kullanan tarafın, diğer sözleşme tarafına sözleşmenin kurulması anında sunduğu sözleşme şartlarıdır. Bu şartların, sözleşmenin harîcen ayrı bir bölümünü oluşturması veya doğrudan sözleşme belgesinde bunlara yer verilmiş olması, kapsamı, hangi yazı şekli kullanılarak kaleme alınmış oldukları veya sözleşmenin șekli önemsizdir.”.

Bir sözleşmede genel işlem şartları kullanımının ve içeriğinin özellikle vurgulanmış olması, hükümlerin açık bir şekilde kaleme alınmış olması halinde hakimin müdahalesine imkan olmamaktadır. Ancak, istediği koşullarda sözleşmeyi akdetme ya da sözleşme akdetmekten vazgeçme olanağı olmayan bir kişi, kendisi için elverişsiz koşullar taşıyan sözleşmeyi, bu elverişsiz koşulların varlığına rağmen, akdetmek durumunda kalabilmektedir. Böyle bir durumda, bu kişinin kendisi için elverişsiz olan koşullara karşı korunması gerekçesiyle, sözleşmenin içerik denetimi devreye girmek durumundadır. Bir kez kurulmuş bir sözleşmeye müdahale edilmemesi yaklaşımına sahip olan liberal düşünce temeline sahip hukuk düzenleri, hakime sözleşmenin içeriğini denetleyebilmesi için genel bir kural getirmediği gibi, genel işlem şartlarının denetlenmesine özgü özel bir norm getirmemiştir ${ }^{50}$. Bu nedenle, genel işlem şartlarının denetimine yardımcı olacak nitelikte bazı hukukî olanaklardan yararlanılmaktadır. Bunlar, şu şekilde siralanabilir ${ }^{5 !}$.

- Emredici hukuk kurallarına aykırılık: Türk hukukunda BK. md.20/II uyarınca, kanunen emredici hükümlere uygun olmayan genel işlem şartları ihtiva eden sözleşmeler, diğer sözleşmelerde olduğu gibi, geçersiz kabul edilir. Genel işlem şartlarının denetimine yardımcı olacak diğer emredici hükümlere; sorumsuzluk anlaşmasına ilişkin sınırlama içeren BK. md.99 ve md. 100, ayıba ve zapta karşı tekeffüle ilişkin BK md.189/II ve md.196, arttırma yoluyla satıma ilişkin BK. md.230/III, otelcinin sorumluluğuna ilişkin BK. md.480, taşıma akdinde taşıyıcının sorumluluğuna ilişkin TTK ${ }^{52}$. md.776, kanundan doğan sorumululuğu sinırlayan sözleşmeleri batıl sayan $\mathrm{KTK}^{53}$. md.111, yardımcı kişilerin kusurlarından doğan zararlar için sorumsuzluk anlaşması yapılamayacağını öngören TTK. md.782 ve md.784, örnek olarak verilebilir.

- Ahlâka aykırılık: Türk hukukunda sözleşme içeriğine ilişkin sınırlamalardan bir diğeri ahlâka aykırılıktır. Toplumda var olan temel değer yargıları, ahlâk düzenine atıf yapan normlar vasitasıyla hukukî yaptırımlarla donatılarak sözleşme içeriğini denetlemektedir. Türk hukukunda buna en iyi

\footnotetext{
5) Atamer, Gcnel İşlem Şartlarının Denetlenmesi, s. 143-144.

${ }^{51}$ Kötz, s. 209. 218, 224; Atamer, Genel İşlem Şartlarının Denetlenmesi, s.146, 151, 160, 168.

178; Yavuz, Genel İşlem Şartlarının Tanımı, Yorumu ve Denetlenmesi, s.579 vd

52 29.6.1956 tarihli ve 6762 sayılı Türk Ticaret Kanunu- RG. 9.7.1956-9353.

${ }^{53}$ 13.10.1983 tarih ve 2918 sayılı Karayollan Trafik Kanunu- RG. 18.10.1983-18195.
} 
örnek, BK. md. 19'dur. Alman Medenî Kanunu md.138'de edim ile karş1 edim arasındaki ilişki, ahlâka aykırılık açısından denetlenmektedir. İsviçre Medenî Kanunu'nda Alman Medenî Kanunu'nun bu maddesiyle benzerlik gösteren madde ise, md.19/2' $\mathrm{dir}^{54}$.

- Gabin: Gabin müessesesi, Roma hukukunda doğan ve gelişen laesio enormis ilkesinin bir yansımasıdır. Bu ilke, bu şekilde sabit bir oranın yasaya aktarılması uygun görülmediği için İsviçre Borçlar Kanunu'na aktarılmazken, Avusturya Medenî Kanunu md. 934-935 tarafından aynen muhafaza edilmiştir ${ }^{55}$. Sözleşmenin bir tarafının zor durumda olmasından, tecrübesizliğinden faydalanılarak edimler arası açı dengesizliğinin mevcut olduğu sözleşmelerde gabin söz konusudur. Türk hukukunda, buna en iyi örnek, BK. md. 21'dir. İsviçre Medenî Kanunu md. 21, standart sözleşmelerin gabine ilişkin denetimini düzenlemektdir.

- Hakkın kötüye kullanılması yasağına aykırılık: Hakların ve kurumların dürüstlük kuralına aykırı olarak kötüye kullanılmasının tespiti yoluyla, sözleşme içeriği denetlenebilir. Türk hukukundaki örneği, MK. md.2'dir. Alman Medenî Kanunu md.24/2'de yer alan ve doğruluk ve dürüstlük kuralı uyarınca standart sözleşmelerde denetim yapılırken, İsviçre Medenî Kanunu md.2'de yer alan doğruluk ve güven kuralına göre Alman hukukuna benzer biçimde standart sözleşmelerin denetimi yapılmaktadır ${ }^{56}$.

- Sözleşmeye dayanan edimi tek taraflı belirleme yetkisinin sınırlandırılması: Türk hukukunda, BK. md. 70'de, çeşit borcunun ifasında seçim hakkını kural olarak borçlu kullanır ve bunu kullanırken de ortalama bir vasfa sahip maldan aşağı mal veremeyeceği hüküm altına alınmıştır. Bu örnekten de anlaşılacağı üzere, taraflardan birine, hakkaniyete uygun şekilde, sözleşmeyi şekillendirme hakkı tanınmıştır. Alman Medenî Kanunu md.315 ise, sözleşmeyi düzenleme yetkisinin karşı tarafa bırakılması halinde, bu yetkinin nasıl kullanılacağını göstermektedir. İsviçre Medenî Kanunu md.71'in de, Alman Medenî Kanunu md.315'i dolaylı olarak karşıladı̆̆ı ileri sürülmektedir ${ }^{57}$.

- Kamu düzeni: Türk hukukunda sözleşme özgürlüğünün bir sınırı olarak kamu düzenine aykırılık hali, BK. md.19/II'de düzenlenmiştir. Sözleşme özgürlüğünün kamu düzeni kavramı ile sınırlandırılabilmesi için kamunun bir menfaatinin tehdit altında olması ve bu menfaatin daha üstün

\footnotetext{
${ }^{54}$ Oğuz, C.: "Standart Sözleşmelerin BK. md. 21 ile 99/2 ve 100/3 Hükümlerine Göre Hakim Tarafından Kontrolü", TBBD 1998/1, s.30.

${ }^{55}$ Kötz, s. 199.

${ }^{56}$ Oğuz, Standart Sözleşmelerin BK. md. 21 ile $99 / 2$ ve 100/3 Hükümlerine Göre Hakim Tarafindan Kontrolü, s. 29-30.

${ }^{57}$ Oğuz, Standart Sözleşmelerin BK. md. 21 ile 99/2 ve 100/3 Hükümlerine Göre Hakim Tarafından Kontrolü, s. 29-30.
} 
bir menfaat olarak belirmesi gereklidir. İsviçre hukukunda da, kamu düzenine aykırılık kavramından faydalanma görüşü hakimdir ${ }^{58}$.

\section{B) Kıta Avrupası Hukuk Sisteminde Çeşitli Ülkelerde, Türk Hukukunda ve Avrupa Birliği Hukukunda Sözleşme Özgürlüğünün Denetimi}

Alman hukukunda, Genel İşlem Şartları Hukukunun Düzenlenmesine İlişkin Kanun, genel işlem şartları kullanılarak akdedilen sözleşmelerin tümünü, iş, miras, aile ve şirketler hukuku alanlarında akdedilen sözleşmeler hariç olmak üzere, konu edinmektedir ${ }^{59}$. Kanun, genel işlem şartının sözleşmenin bir parçası olarak geçerli kabul edilebilmesini, şartın sözleşmenin yapıldığ 1 sırada açık bir şekilde diğer âkidin dikkatine sunulması (md.2/1 b.1); karşı âkide genel işlem şartının içeriğinin anlaşılması için gerekli olan süre ve imkanın verilmiş olması (md.2/1 b.2) ile karşı âkidin genel işlem şartının uygulanmasını kabul etmesi şartlarına bağlamıştır. Dolayısıyla, tarafların karşıllklı ve birbirine uygun irade beyanları aranmış, uygunluk bulunmayan hallerde, ilgili şart sözleşmenin bir parçası olarak kabul edilmemiştir ${ }^{60}$. Beklenilmeyen ve olağan dışı şartlar olarak anılan hükümlerin de. Sözleşmenin bir parçası olarak kabul edilemeyeceği hüküm altına alınmıştır (md.3) $)^{61}$. Yine iyiniyete aykırı, hakkaniyete uymayan veya karşı âkit tarafından makul surette kabullenilmeyecek derecede elverişsizlik oluşturan sözleşme şartları da etkili kabul edilmemektedir (md.9/1). Bu maddenin yorumlanmasinda tereddüde düşüldüğü takdirde, taraflardan birinin sözleşmeden doğan temel hak ve ödevlerini sözleşmenin amacını tehlikeye sokacak veya engelleyecek şekilde değiştiren sözleşme şartları ile tarafların aksini kararlaştırdıkları hükümlerin temel fikri ile telif edilebilir olmayan sözleşme şartları, karşı âkit için makul olmayacak derecede elverişsizlik oluşturan sözleşme şartları olarak düşünülecektir (md.9/2) ${ }^{62}$. Ayrıca, anılan Kanunun 10. maddesinde, geçerlilik bakımından hakimin takdirine bağlı olarak hüküm ifade edecek bir gri liste (grey list) ve 11. maddesinde ise, yasaklanmış sözleşme şartlarını içeren bir kara liste (black list) yer almaktadır ${ }^{63}$.

\footnotetext{
${ }^{58}$ Atamer, age, s.187

${ }^{59}$ Kötz, age, s. 218; Atamer, age, s.40, 15; Güngör, age, s.48; Yavuz, agm, s.583.

${ }^{60}$ Atamer, age, s.41; Güngör, age, s.49.

${ }^{61}$ Tekinalp, Ü.: Türk Bankacılık Uygulamasında Genel İşlem Şartları, Prof. Dr. Ernst E. Hirsch'in Hatırasına Armağan, Banka ve Ticaret Hukuku Araştırma Enstitüsü, Ankara 1986, s. 142-143.

${ }^{62}$ Tandoğan, H.: Tüketicinin Korunması ve Sözleşme Özgürlüğünün Bu Açıdan Sınırlanması, AÜHF Yay., No.416 Konferanslar Dizisi No.2, Ankara 1977, s.32.

${ }^{63}$ Tandoğan, agm, s.32-34.
} 
Avusturya hukukunda ise, yasa koyucu genel olarak tüketici sözleşmelerinde yer alan adil olmayan hükümleri engellemeyi hedeflemiştir. 1979 yılında yürürlüğe giren Tüketicinin Korunması Hakkında Kanun'da 6. paragraf tüketici ile aktedilen sözleşmelerde geçersiz sayılacak sözleşme hükümlerini düzenlemiştir. Bu kanunda, Avusturya Medenî Kanunu ile bir değişiklik yapılmış ve genel olarak sözleşmelerde butlanı düzenleyen md. 879'a eklenen bir fıkra ile genel işlem şartları içinde yer alan hükümlerin, somut olayın özelliklerini dikkate alındığında, taraflardan birini aşırı derecede mağdur etmesi halinde batıl sayılacağı öngörülmüştür. Avusturya hukukunda sorun, salt genel işlem sorunu olarak görülmemiştir ${ }^{64}$.

İsviçre sözleşmeler hukuku, 17. ve 18. yy.'da geliştirilmiş olan sözleşme özgürlüğü ilkesini, özelliklerini büyük ölçüde muhafaza ederek sürdürmektedir. Buna göre, sözleşme özgürlüğü ilkesinin temel üç unsuru vardır ${ }^{65}$ :

- Sözleşmenin karşı tarafını seçerek, bir sözleşmeyi akdetmek ya da etmemek: Kamu hizmeti, kamu taşımacılığı ve anti-tröst hukuku kapsamında olan özel bir yasal düzenleme sözleşme yapılmasını emretmediği sürece sözleşme aktedilmesi serbesttir.

- Sözleşmenin içeriğini oluşturacak hükümlerin taraflarca belirlenmesi: Sözleşmenin her iki tarafı sözleşmede yer almasını istedikleri şartları kendi takdirlerine göre belirleyebilirler. Ayrıca, İsviçre hukukunda "özgürlük" kavramına, açı bir yasal dayanağı olmayan sözleşme türlerinin de kabul edilebilirliği anlamı yüklenmiştir. Bu sözleșmelere örnek verilecek olursa;

daha önce yapılmış bir sözleşmeyi ortadan kaldıran veya sözleşmenin hükümlerini değiştiren bir sözleşme (İsviçre Borçlar Kanunu md.115)

- sözleşmenin sadece bir tarafına veya her iki tarafına birden gelecekte bir sözleşme yapma yükümlülüğü yükleyen sözleşme (Vorvertrag) (İsviçre Borçlar Kanunu md.22)

- üçüncü kişi yararına sözleşme (İsviçre Borçlar Kanunu md.112)

- sözleşmeye başka bir kişinin ikame edilmesi (İsviçre Borçlar Kanunu md.164-174)

- İsviçre Borçlar Kanununun özel hükümler kısmında yer alan sözleşme tiplerinden ayrılma özgürlügü: $\mathrm{Bu}$, sözleşme taraflarının müttefiken Kanun tarafından öngörülen sözleşme tiplerinden farklı bir

\footnotetext{
${ }^{64}$ Atamer, age, s.42.

${ }^{65}$ Dessemontet, F.- Ansay, T.: Introduction to Swiss Law, 3rd Ed., The Hague, Boston and London, Kluwer/Schulthess, s.5, www.eugenbucher.ch, 10.12.2003.
} 
sözleşme tipi oluşturmayı kararlaştırabilmelerini sağlayan sözleşme özgürlüğü anlayışıdır ${ }^{66}$.

İsviçre hukukunda, genel işlem şartları sorunu ise, ne özel bir yasaya konu olmuş ne de bir tüketicinin korunması yasası çerçevesinde düzenlenmiştir. 1988 yılında yürürlüğe giren Haksız Rekabetin Önlenmesine İlişkin Kanun'un 8. maddesinde, genel işlem şartları kullanımının bazı hallerde bir haksız rekabet oluşturacağı öngörülerek, genel işlem şartlarının içerik denetiminin nasıl yapılacağı düzenlenmiștir. İsviçre Borçlar Kanunu md.256/II (a) ve 288/II (a) hükümleri de genel işlem şartlarına ilişkin düzenlemeler içermektedir. Bu hükümlere göre, adi kira veya hasılat kirası sözleşmelerinde kiraya verenin, kiralananı kararlaştırılan şekilde kullanmaya elverişli şekilde teslim etmek ve sözleşme süresi boyunca bu şekilde muhafaza etmek konusundaki sorumluluğunu genel işlem şartı yoluyla ortadan kaldıran veya sınırlandıran hükümler geçersizdir ${ }^{67}$.

Fransa'da, 10.1.1978 tarihli yasa ile kurulmuş olan komisyon, dürüst olmayan ticarî faaliyetlere ilişkin olarak satıcıların kullandıkları sözleşme tiplerinin araştırılması ve dürüst olmayan sözleşme koşullarının iptalini ya da yeniden düzenlenmesini önerme yetkisine sahiptir ${ }^{68}$.

Hollanda hukukunda, Alman hukukuna benzer düzenlemeler yer almaktadır. Hollanda Standart Şartlar Kanun Taslağında ${ }^{69}$, makul olamayacak surette külfet getiren (unreasonably onerous), dayanılması güç, haksız sözleşme şartlarının geçersiz sayılabileceği öngörülmüştür (md.2/2).

Avrupa Birliği Konseyi, 5 nisan 1993 tarihinde "Tüketici Sözleşmelerindeki Kötüye Kullanılabilir Hükümler Hakkında Direktif'i kabul etmiştir ${ }^{70}$. AB'ye üye devletlere, en geç 31 Aralık 1994 tarihine kadar, Direktifi iç hukuklarına aktarmaları için süre tanınmıştır. 5 Nisan 1993 'te Lüksemburg'da toplanan $\mathrm{AB}$ üyesi devletler, gerçek kişi tüketicilerin korunması ve bu konuda $\mathrm{AB}$ 'de yüksek bir koruma standardı sağlaması amacıyla, tüketici sözleşmelerinde yer alan haksız sözleşme şartlarına ilişkin olarak üye devletlerin iç hukuklarının uyumlaştırılmasını öngören bir direktif hazırlamıştır (md. 1/1). Üye devletlerin tüketici lehine, direktifin öngörduiğüi korumadan daha yüksek düzeyde koruma sağlayan düzenlemeler sevk edebilmesi de öngörülmüștür (md.8). Direktif, tarafların pazarlık gücünün eşit olmamasıyla değil, mal ve hizmetleri üreten yada tedarik eden kişinin tüketiciye nazaran sahip olduğu yüksek ekonomik gücü kötüye kullanması

\footnotetext{
${ }^{66}$ Dessemontet- Ansay, age, s.28.

${ }^{67}$ Atamer, age, s.44

${ }^{68}$ Yavuz, agm, s.585.

(9) The Dutch General Conditions Bill 1981.

${ }^{70}$ EC OJ L 93/13 -21.4.1993.
} 
ile ilgilenmiştir. Direktifin kabul ettiği kriter, sözleşme şartının "haksız" (unfair) olmasidir ${ }^{71}$.

Direktifte yer alan hükümler, Avusturya hukukundaki düzenlemeler gibi sadece içerik denetimine ilişkindir. pazarlık konusu yapılmayan hükümlerin özellikle genel işlem şartlarının sözleşmenin parçası haline gelip gelmediği sorununa ilişkin olarak, Direktifte herhangi bir açık düzenleme yer almamaktadır. İçerik denetimi ise, tek tek pazarlık konusu yapılmamış hükümler açısından söz konusudur. Bu hükümlerin tek bir sözleşmede kullanılmak üzere mi yoksa birden fazla kullanım niyetiyle mi kaleme alındığ müşterinin ilgili hükümlerin oluşumuna etki edip edemediği, yani "take it or leave it"durumunda olup olmamasıdır. Hangi hükümlerin tek tek pazarlık konusu yapılmamış sayılacağını, Direktif md.3/2 'de belirlemektedir. Buna göre, ilgili hükmün önceden saptanmış olması ve özellikle bunun "standart sözleşme" yoluyla gerçekleşmiş olması nedeniyle, tüketicinin hükmün içeriğine bir etkide bulunamamış olduğu hallerde pazarlık konusu yapılmamış bir hükmün varlığı kabul edilecektir. Direktifin 3. maddesi, tek tek pazarlık konusu yapılmamış olan her türlü sözleşme hükmü için geçerli maddi denetim ölçütünü tespit etmektedir. Belirleyici olan, dürüstlük kuralına aykırı olarak tüketici aleyhine akdî hak ve borçların dağılımında önemli ve haksız bir orantısızlık olmasıdır. Direktifin ekinde, üye ülkeler tarafından bâtıl sayılabilecek hükümlerin bir listesi yer almaktadır ${ }^{72}$.

1994 y1lının sonlarına doğru International Institute for the Unification of Private Law- UNIDROIT'in çalı̧̧malarıyla ortaya çıkan ve Roma'da yayınlanan Uluslar arası Ticarî Sözleşmeler İçin İlkeler (Principles of International Commercial Contracts), anlaşmaya (consensus) dayalı olan ve uluslararası ticarî sözleşmeler için genel kurallar içeren ilkelerdir ${ }^{73}$. Anılan ilkelerin gerek ulusal gerekse uluslararası plânda, kanun koyucular için model işlevi görmesi, uluslararası yeknesak hukukun kurallarının yorumlanması ve boşlukların doldurulmasında kullanılabilir nitelikte olması nedeniyle $^{74}$, sözleşme özgürlüğü ilkesine ilişkin düzenlemeleri, çalışma konumz açısından önem taşımaktadır. UNIDROIT 1994 İlkelerinin "Genel Hükümler" başlıklı birinci bölümünde yer alan "Sözleşme Özgürlüğü" başlıklı md.1.1'de yer alan bu düzenlemeye ilişkin yapılan yorumda, sözleşme özgürlüğü ilkesinin uygulanmasında bazı istisnaların olabileceği vurgulanmıştır ${ }^{75}$. Buna göre, devlet kamu menfaatini korumak amacıyla, bazı

\footnotetext{
${ }^{71}$ Güngör, age, s. 50/51

${ }^{72}$ Atamer, age, s.44-45; Kötz, age, s.218, Maxeiner, J.R.: "Standart-Terms Contracting in the Global Electronic Age: European Alternatives", The Yale Journal of International Law, Winter 2003, Vol.28, No.I, p.131.

${ }^{73} \mathrm{http}: / / \mathrm{www}$.unidroit.org, 24.12.2003.

${ }_{74}^{7}$ Oğuz, Sözleşmeler Hukuku Alanında HukukunBirleştirilmesi, s.56-58.

${ }^{75}$ UNIDROIT Principles, Black Rules and Comments, http://unidroit.org, 24.12.2003.
} 
ekonomik sektörleri rekabete açık olan alanlardan muaf tutabilir. Bu durumu açıklayan en iyi örnek, bir kamu kurumunun tekel biçimindfe sahip olduğu mal ve hizmet sağlama yetkisini, olanakları dahilinde kullanarak, belli ölçülerde istediği kişilerle sözleşme akdetmesi halidir. Bu durum, sözleşme özgürlügünün sınırlandırılmasına iyi bir örnektir. Ayrıca, UNIDROIT İlkeleri md.1.4'te, "emredici hükümler" bașlıklı hükmü uyarınca, devlet tarafından yürürlüğe konan kamu veya özel hukuk karakterli emredici yasal düzenlemeler; anti-tröst yasağı, haksız sözleşme şartlarına ilişkin kanunlar, fiyat ve döviz kontrolü uygulamaları gibi düzenlemelerle, sözleşme taraflarının sözleşme özgürlüğü ilkesi çerçevesinde iradelerinin emredici hükümlerle sinırlanması söz konusudur ${ }^{76}$.

Türk hukukuna baktığımızda, ilk olarak 1981 yılında İstanbul Ticaret Odası adına Prof. Dr. Ömer Teoman tarafından genel işlem şartları denetimine ilişkin ayrıntılı bir yasa tasarısı hazırlanmış ve dönemin Sanayi ve Ticaret Bakanlığı'na iletilmiş olduğunu görmekteyiz ${ }^{77}$. Ancak bu tasarı kanun haline dönüştürülememiştir. 1995 'te yürürlüğe giren Tüketicinin Korunması Hakkında Kanun ${ }^{78}$ içinde ise, genel işlem şartlarına ilişkin bir düzenleme yer almamaktadır. TKHK. md. 10'da düzenlenen tüketici kredisi sözleşmelerinin vadesinden önce kapatılmasına ilişkin şartlar, borçlunun temerrüde düşmesinin hukukî sonuçları veya istenecek teminatlar konusunda sözleşmede açıklık olması şartı aranıyorsa da, bu hükümlerin bilfiil ne gibi düzenlemeler ihtiva ettiği ve müşteriyi mağdur edip etmediği sorunuyla ilgilenilmemiştir ${ }^{79}$.

Türk Ticaret Kanunu'nun çeşitli maddelerinde ise, dolaylı da olsa genel işlem şartları sorunu ile ilgilenildiği gözlenmektedir. TTK. md. 766'ya göre, taşıma sözleşmesinde, kanunun taşıyana yüklediği sorumluluğun önceden kaldırılması veya sınırlandırılması sonucunu doğuran bütün şartlar, özellikle bu şartların "umumî şartnamelere" konulmuş olması halinde geçersiz kabul edilir. TTK. md. 1266/II'ye göre ise, ilgili bakanlıkça tasdik edilmemiş olan veya zahmetsizce okunamayacak olan şartları kullanan sigortacı, genel şartlarda sigorta ettiren aleyhine yer alan hükümlerin yerine kanun hükümlerinin uygulanmasına katlanmak zorundadır.

Genel işlem şartları kullanımı halinde, sözleşme içeriğine müdahale konusunda hakimi, çok sınırlı bir alanda bile olsa, yetkilendiren ilk hüküm, Sermaye Piyasası Kurulu'nun Aracılık Faaliyetleri ve Aracı Kuruluşlara

${ }^{76}$ Bonell, M.J.. The UNIDROIT Principles of International Commercial Contracts, Nature, Purposes and First Experiences in Practice, http://www.unidroit.org, 24.12.2003, p.3.

${ }^{77}$ Tekinalp, Ü.: Banka Hukukunun Esasları, İstanbul 1988, s.264.

${ }^{78} 4077$ sayllı ve 23.2.1995 tarihli K., RG. 8.3.1995-22221. Bu Kanun, daha sonra 4822 sayilı ve 6.3.2003 tarihli Tüketicinin Korunması Hakkında Kanunda Değişiklik Yapılmasına Dair Kanun (RG.14.03.2003-25048) ile değişikliğe uğramıștır.

${ }^{79}$ Atamer, age, s.47-48 
Illişkin Esaslar Tebliği'nde yapılan bir değişikliktir ${ }^{80}$. Genel olarak sermaye piyasası araçlarının alım satımına aracılık etmek üzere, aracı kurum ile müşteri arasında akdedilecek çerçeve sözleşmede bulunması gereken asgarî hususları düzenleyen 47. maddenin değiştirilen üçüncü fıkrası ile bu çerçeve sözleşmenin içerik sınırları saptanmıştır. Buna göre; çerçeve sözleşmesinde $^{81}$, Kurul düzenlemelerine ve borsa mevzuatına aykırı hükümler ile müşterilerin haklarını ciddi şekilde zedeleyici ve aracı kuruluş lehine tek taraflı olağanüstü haklar sağlayan hükümlere ve emirlerin ispatının müşteriye yüklenmesine ilişkin hükümlere yer verilemez. Sözleşmede hüküm bulunmayan hallerde genel hükümler uygulanır. Bu fıkra hükmü aracı kuruluşlar ile müşterileri arasında düzenlenecek halka arza aracılık, portföy yöneticiliği, yatırım danışmanlığı, repo ve ters repo, kredili menkul kıymet, açığa satış ve menkul kıymetlerin ödünç işlemi sözleşmeleri ile Kurul düzenlemeleri çerçevesinde müşteriler ile yapılabilecek diğer sözleşmelere ve portföy yönetim şirketleri ile müşterileri arasında düzenlenecek portföy yöneticiliği sözleşmelerine de uygulanır.

\section{II- Common Law Sisteminde Sözleşme Özgürlüğünün Sinirlandırılması}

A) İngiliz Hukuku Açısından

01.02.1978 tarihinde Ingiltere'de yürürlüğe giren Adil Olmayan Sözleşme Hükümleri Hakkında Kanun (Unfair Contract Terms Act 1977), bireysel ve standart sözleşmeleri kapsamaktadır. Anılan Kanun, içerik denetimine ilişkin bir çerçeve norm getirmek yerine, belirli bazı sorunlara ilişkin hükümler getirmiştir. Kanunda esas itibariyle, bireysel ve standart sözleşmelerde yer alan ve ticarî faaliyet yürüten âkit tarafın hukukî sorumluluğunu kaldıran veya sınırlayan haksız sorumluluk kayıtları ile

${ }^{80}$ Sermaye Piyasası Kurulununun serî:V No. 19 Aracılık Faaliyetleri ve Aracı Kuruluşlara İlişkir Esaslar Tebliğinde Değişiklik Yapılmasına Dair Tebliğ, RG. 8 Ekim 1998-23487.

${ }^{81}$ Çerçeve sözleşme (Rahmenvertrag-Mantelvertrag-manto sözleşme), ileride aynı türden birden fazla sözleşme akdetmeye niyetli olan kişilerin, her bir sözleşmenin kuruluşu esnasında ayrıca kararlaştırılmasına gerek kalmaksızın, belirli birtakım şartların kısmen veya tamamen bu sözleşmelerde yer almasında şimdiden mutabık kalmalarıdır. Özünde, ileride yapılması muhtemel münferit sözleşmelerin önceden çerçeve sözleşme ile saptanmış bir içeriğe sahip olması, diğer bir deyişle, çerçeve sözleşmenin gelecekteki sözleşmelerin içeriğinin önemli bir bölumünü teşkil etmesi yatmaktadır. Sözleşme özgürlüğü ilkesi doğrultusunda, çerçeve sözleşme akdedilmesine herhangi bir engel bulunmamaktadır. Çerçeve sözleşme kavramı ile genel işlem şartları arasında yakın ilişki bulunmakla birlikte, bunlar farklı müesseselerdir. Genel işlem şartları, taraflardan birinin karşı âkitle ileride yapacă̆ı sözleşmelere yönelik olarak tek taraflı olarak belirlediği bir özel normlar demetidir. Oysa çerçeve sözleşme, şu haliyle bile tarafların ortak iradelerinin ürünü olarak bir "sözleşme" niteliğindedir. Barlas, N.: Çerçeve Sözleşme Kavramı ve Çerçeve Sözleşmelerin Özellikleri, Prof. Dr. Erdoğan Moroğlu'na 65. Yaş Günü Armağan, İstanbul 1999, s.808-809. 
tazminat kayıtlarının yer aldığı menkul satımı (sale) veya taksitle satım (hire-purchase) sözleşmelerine ilişkin düzenlemeler içermektedir. Kanun, bazı sözleşme şartlarını geçersiz sayarken, diğerlerinin "makul olma" kriterine (reasonableness test) göre değerlendirilmesini öngörmektedir ${ }^{82}$.

Tüketici akitlerinde haksız sözleşme şartlarına ilişkin AB direktifinin İngiltere iç hukukuna aktarılması için öngörülen sürenin yetersiz olması nedeniyle, direktif hükümleri ayrı bir düzenleme olan Tüketici Sözleşmelerinde Adil Olmayan Hükümler Hakkında Tüzük (The Unfair Terms in Consumer Contracts Regulations 1994), 01.07.1995 tarihinde yürürlüğe girmiştir ${ }^{83}$.

İngiltere'de en yüksek dereceli mahkeme olan House of Lords'un ${ }^{84}$ Director General v. First National davası ${ }^{85}$ sonucu verdiği kararında, Tüketici Sözleşmelerinde Adil Olmayan Hükümler Hakkında Tüzüğün 1995 'ten itibaren dört ayrı versiyonunda yer alan "haksız şartlar" (unfair terms) kavramının tanımı yapılmıştır. Buna göre, haksız şart, tüketici zararına olarak, iyi niyete aykırı ve tarafların sözleşmeden doğan hak ve yükümlülükleri arasında önemli ölçüde bir dengesizliğe yol açan bir şarttır. İyi niyet ölçütui ise, her somut olayın şartlarına göre yorumlanarak dikkate alınmalıdır.

\section{B) Amerikan Hukuku Açısından}

Amerikan Hukukunda, işletmeler ile girişilen standart sözleşme şeklinde sözleşmelerde yer alan şartlar, hakkaniyete aykırılık ilkesi (principle of unconscionability) ve doktrini kapsamında ele alınmakta ve hakkaniyete aykırı sözleşme şartlarına hukukî sonuç bağlanmamaktadır ${ }^{86}$.

Yeknesak Ticaret Kanunu ${ }^{87}$ (Uniform Commercial Code) 2-302'de yer alan hakkaniyete aykırılık ilkesi, sözleşmenin konusu ile sözleşme taraflarının hukukî durumunun araştırılması esasına dayanmaktadır ${ }^{88}$. Kanun, esas itibariyle standart biçimde yapılan menkul mal satımlarına uygulanmak üzere tasarlanmış olmakla birlikte, tüm sözleşme tiplerini kapsayacak biçimde uygulanmaktadır. Temel amaç, güçlü âkit tarafın pazarlık gücünü kötüye kullanmasının önüne geçilmesi ve zayıf tarafın beklenmeyen bir hukukî sonuçla karşı karşıya kalmasının engellenmesidir.

${ }^{82}$ Atamer, age, s.46-47; Güngör, age, s.44-45.

${ }^{83}$ Atamer, age, s.46-47; Güngör, age, s.44-45; Kötz, s.218.

${ }^{84}$ Oğuz, Karşılaştırmalı Hukuk, s.268.

${ }^{85}$ Director General of Fair Trading v First National Bank 2001, UKHL 52, All England Law Reports (2002) I All ERHL, p.105.

${ }^{86}$ Kötz, age, s.219.

${ }^{87}$ National Conference of Commissioners on Uniform State Laws'un çalışmaları sonucu oluşan oluşturulmuş olan ve ABD'nin bütün federe devletlerinde uygulanan bir model kanundur. Ayrıntılı bilgi için bkz.Oğuz, Karşılaştırmalı Hukuk, s.59.

${ }^{88}$ Maxciner, agm, s.113-116. 
Hakkaniyete aykırılık ilkesi, hem sözleşmenin kurulması hem de sözleşmede yer alan şartlar itibariyle pazarlık gücünün kötüye kullanılmasında uygulama alanına sahiptir. Ancak, bununla birlikte, hakkaniyete aykırı ya da haksız olarak nitelendirilebilecek tüm sözleşme şartları değil, güçlü âkit tarafın pazarlık gücünü kötüye kullanması sonucunda sevk edilmiş hakkaniyete aykırı ya da haksız sözleşme şartları konu edilmiştir ${ }^{89}$.

Common Law sisteminin bel kemiği olan içtihat hukukunun önemli bir kaynağı olan Restatement'lara ${ }^{90}$ bakıldığında ise, sözleşme özgürlüğünün her şeyden evvel, kanunlar (statute) ile yasaklanmış hususlarda ve common law politikasına aykırı olan hallerde sınırlandırılacağı gözlemlenmektedir ${ }^{91}$

\section{SONUÇ}

Avrupa Sözleşmeler Hukukunda ve tüm çağdaş hukuk düzenlerinde toplumsal ilişkileri düzenleme işlevine sahip olan sözleşme, hukukî ve tarihî temellerini Roma Hukuku'nda bulmuştur. Hukuken son derece önemli olan sözleşmeden doğan hak ve yükümlülüklerin, yine hukukun genel ilkelerinden doğruluk ve güven ilkesine gerçek anlamda ihtiyaç duyulmaktadir.

Klâsik Roma Döneminden bu yana, âkit taraflardan birinin açık şekilde zararına ve hakkaniyete aykırı olarak sözleşmelerde yer alan edimlerarası dengesizlik hakkının kötüye kullanılması olarak kabul edilmiş ve bu şekilde yapılmış olan sözleşmeler geçersiz kabul edilmiştir.

19. yy.'da başlayan kodifikasyon hareketleri ile, sözleşme özgürlüğ ỉ ilkesi kendine, çağdaş hukuk düzenlerinde tam anlamıyla yer bulabilmiştir. Sosyal ve ekonomik gelişmelerin etkisiyle güçlenen işletmelerin tekeline girmeye başlayan ticarî hayatın zamanla tecrübesiz, bilgisi olmayan zayıf olarak nitelenen kişilerin işlemesi nedeniyle, sözleşme hukukunda sözleşme özgürlüğü ilkesinin sınırlandırılması ihtiyacı baş göstermiştir.

Sözleşme özgürlüğünün sınırlandırılması, gerek ulusal hukuk düzenlerinde gerek bölgesel entegrasyonlarda ve gerekse uluslar arası plânda kabul görmüş ilkeler topluluklarında üzerinde önemle durulan bir konu olmuş ve sözleşme hukukundaki gelişmelere paralel olarak daha da titiz bir şekilde, gittikçe artan bir ehemmiyetle üzerinde durulacağa benzer bir konu olacaktır.

${ }^{89}$ Güngör, age, s.46-48; Maxeiner, agm, s.115-123.

${ }^{90}$ Restatements bütün hukuk alanlarındaki önemli kararlara yer veren ve bu kararları karşılaştırmalı biçimde eleştiren kararlar derlemesidir. Ayrıntılı bilgi için bkz. Oğuz, Karşılaştırmalı Hukuk, s.299 vd..

${ }^{91}$ Restatements of the Law, Contracts, Vol. I, Sections 1-346 as adopted and promulgated by the American Law Institute at Washington D.C., May 6, 1923, ALI Publications, St. Paul 1932, p.181 vd. 


\section{KAYNAKÇA}

ALI Publications: Restatements of the Law, Contracts, Vol. I, Sections 1346 as adopted and promulgated by the American Law Institute at Washington D.C., May 6, 1923, ALI Publications, St. Paul 1932.

All England Law Reports, (2002)1 All ERHL.

Atamer, Y.: Sözleşme Özgürlüğ̈̈nün Sıntrlandırılması Sorunu Çerçevesinde Genel İslem Şartlarının Denetlenmesi, İstanbul 2001.

Barlas, N.: Çerçeve Sözleşme Kavramı ve Çerçeve Sözleşmelerin Özellikleri, Prof. Dr. Erdoğan Moroğlu'na 65. Yaş Günü Armağanı, İstanbul 1999, s.807-828.

Basedow, J.: Avrupa Özel Hukukunun Doğuşu, Çev.: Arzu Ŏ̆uz, Ä̈HFD 2003, C.52, S.3, s. 1-18.

Bonell, M.J.. The UNIDROIT Principles of International Commercial Contracts, Nature, Purposes and First Experiences in Practice, http://www unidroit.org, 24.12.2003.

Dessemontet, F.- Ansay, T.: Introduction to Swiss Law, 3rd Ed., The Hague, Boston and London, Kluwer/Schulthess, http://www.eugenbucher.ch, 10.12.2003.

Eren, F.. Borçlar Hukuku Genel Hükümler, C.I, İstanbul 1998.

Güngör, G.: Milletlerarası Özel Hukukta Tüketicinin Korunması, Ankara, 2000.

Isaacs, N.: The Standardizing of Contracts, Yale Law Journal, C.27, 19171918, s.34-48.

Iustinianus: Institutiones, (Çev.: Ziya Umur), Istanbul 1968.

Karadeniz-Çelebican, Ö.: Roma Hukuku, AÜHF Yay. No.518, Ankara 1997.

Kılıçoğlu, M. A.: Borçlar Hukuku Genel Hükümler, Cilt I, Ankara 2001.

Koschaker, P./ Ayiter, K.: Modern Hususî Hukuka Giriş Olarak Roma Hususî Hukukunun Ana Hatları, Ankara 1975.

Köhler, H.: BGB, Allgemeiner Teil, 18. A., München 1983.

Kötz, H.: Europäisches Vertragsrecht, Band I, Abschluss, Gültigkeit und Inhalt des Vertrages, die Beteiligung Dritter am Vertrag, Tübingen 1996.

Maxeiner, J.R.: "Standart-Terms Contracting in the Global Electronic Age: European Alternatives", The Yale Journal of International Law, Winter 2003, Vol.28, No.I,

Merz, H.:Vertrag und Vertragschluss, Freiburg 1988, p.109-177

Meyer, R./Spasche, A.: Roman Law, The Recovery of Benefits Conferred under Illegal or Immoral Transactions, Uni. Of Aberdeen 2002, s.5, http://www.abdn.uk, 10.12.2003. 
Oğuz, A :: Karşıllaştırmalı Hukuk, Ankara 2003.

Oğuz, A.: Sözleşmeler Hukuku Alanında Hukukun Birleştirilmesi, AÜHFD 2000, S.1, s.31-65.

Oğuz, C.: "Standart Sözleşmelerin BK. md. 21 ile 99/2 ve 100/3 Hükümlerine Göre Hakim Tarafından Kontrolü”, TBBD 1998/1, s.2537.

Rado, T.: Roma Hukuku Dersleri, "Borçlar Hukuku”, İstanbul 1997.

Raiser L.:Vertragsfreiheit Heute, Juristenzeitung, No: 1, Tübingen, 5.Ocak 1958, s.1-8.

Sohm, R.: The Institutes (Çev. James Crawford Ledlie), W.M.W Gaunt\& Sons. Inc. 1994, s.372.

Tandoğan, H.: Tüketicinin Korunması ve Sözleşme Özgürlïğünün Bu Açıdan Sınırlanması, AÜHF Yay., No.416 Konferanslar Dizisi No.2, Ankara 1977.

Tekinalp, Ü.: Türk Bankacılık Uygulamasında Genel İşlem Şartları, Prof. Dr. Ernst E. Hirsch'in Hatırasına Armağan, Banka ve Ticaret Hukuku Araştırma Enstituisü, Ankara 1986, s. 119-160.

Tekinalp, Ü:: Banka Hukukunun Esasları, İstanbul 1988.

Yavuz, N.: Genel İşlem Şartlarının Tanımı, Yorumu ve Denetlenmesi, Yargitay Dergisi, 1999, C.25, S.4, s.570-603.

Zimmerman, R.: The Law of Obligations, Roman Foundations of the Civilian Tradition, Johannesburg 1992.

http://www.unidroit.org, 24.12.2003. 


\section{KISALTMALAR CETVELI}

$\begin{array}{ll}\text { age } & : \text { adı geçen eser } \\ \text { agm } & : \text { adı geçen makale } \\ \text { AB } & : \text { Avrupa Birliği } \\ \text { ALI } & : \text { American Law Institute } \\ \text { AÜHF } & : \text { Ankara Üniversitesi Hukuk Fakültesi } \\ \text { BGB } & : \text { Bürgerliches Gesetzbuch } \\ \text { Bkz. } & : \text { bakınız } \\ C & : \text { Cilt } \\ \text { Çev. } & : \text { çeviren } \\ \text { EC } & : \text { European Council } \\ \text { http:// } & : \text { Hypertext Transfer Protocol } \\ m d & : \text { madde } \\ \text { No } & : \text { numara } \\ \text { OJL } & : \text { Official Journal Legislation } \\ \text { p. } & : \text { page } \\ \text { pp. } & : \text { page to page } \\ \text { RG. } & : \text { Resmî Gazete } \\ S . & : \text { Sayı } \\ \text { s. } & : \text { sayfa }\end{array}$

TBBD. : Türkiye Barolar Birliği Dergisi

vd. : ve devamı

Vol. : Volume

www : world wide web

Yay. : yayınları

yy. $\quad$ : yüzy1 